JURNAL SEKRETARIS \& ADMINISTRASI BISNIS

Jurnal homepage http /ljurnal asmtb ac id/inde $\times \mathrm{php} / \mathrm{jsab}$

\title{
DRIVING FACTORS OF CONSUMER TO PURCHASE FURNITURE ONLINE AT IKEA INDONESIA WEBSITE
}

Trisha Gilang Saraswati

Program Studi Administrasi Bisnis, Fakultas Komunikasi dan Bisnis, Universitas Telkom trishasaraswati@telkomuniversity.ac.id

\section{ARTICLE INFO}

Article history:

Received $19^{\text {th }}$ January 2018

Received in revised form $07^{\text {th }}$ February 2018

Accepted $15^{\text {th }}$ February 2018

Keywords:

Retail Business,

Online Purchase Decision,

Factor Analysis
Kata Kunci:

Bisnis Ritel,

Keputusan Pembelian Online,

Analisis Faktor

\section{ABSTRACT}

The tendency of consumers in shopping for furniture is very different from shopping for other goods or services, because furniture is expected to be stored and used in a long time. Considering that, consumers tend to want to shop directly to offline stores in order to see, feel and check quality directly because of many aspects assessed such as the quality of materials, models, colors and more. Behind the trend to shop furniture offline, IKEA continues innovating to improve the performance of its website so that consumers can shop online. Therefore, this study intends to analyze what factors are driving consumers in shopping for furniture online especially on the website of IKEA Indonesia. From two grounded theory employed, there are 14 factors that can influence consumers to buy online. This data analysis uses Principal Component Analysis (PCA), a factor analysis method that extracts factors by using total variance in the analysis. From data calculation, it is known that there are 8 driving factors of consumer to purchase furniture online on IKEA Indonesia's website: Enjoyment, Perceived Risk, Efficiency, Service \& Merchandise Quality, Ease of Navigation, Price Attractiveness, Flexibility and Reliability. By knowing what factors can affect consumers in doing online shopping for furniture, companies in this case IKEA Indonesia can optimize the use of its website in accordance with influential factors.

Kecenderungan konsumen dalam berbelanja furnitur sangat berbeda dengan belanja barang atau jasa lainnya, karena furnitur diharapkan bisa disimpan dan digunakan dalam waktu lama. Mempertimbangkan hal tersebut, konsumen cenderung ingin berbelanja langsung ke toko offline agar bisa melihat, merasakan dan memeriksa kualitas secara langsung karena banyak aspek yang dinilai seperti kualitas bahan, model, warna dan lainnya. Namun dibalik kecenderungan tersebut, IKEA terus berinovasi meningkatkan kinerja website-nya supaya konsumen dapat berbelanja secara online. Penelitian ini bertujuan untuk menganalisis faktor apa saja yang mendorong konsumen berbelanja furnitur secara online terutama di situs IKEA Indonesia. Dari dua teori dasar yang digunakan pada penelitian ini, terdapat 14 faktor yang dapat mempengaruhi konsumen untuk membeli furnitur secara 
online. Analisis data ini menggunakan Principal Component Analysis (PCA), sebuah metode analisis faktor yang mengekstrak faktor dengan menggunakan varian total dalam analisis. Dari perhitungan data diketahui bahwa terdapat 8 faktor pendorong konsumen untuk membeli furnitur secara online di website IKEA Indonesia yaitu Enjoyment, Perceived Risk, Efficiency, Service \& Merchandise Quality, Ease of Navigation, Price Attractiveness, Flexibility dan Reliability. Dengan mengetahui faktor apa saja yang dapat mempengaruhi konsumen dalam berbelanja furnitur secara online, perusahaan dalam hal ini IKEA Indonesia dapat mengoptimalkan penggunaan situsnya sesuai dengan faktor-faktor yang dapat mempengaruhi konsumen.

@ 2018 ASMTB PRESS

\section{Introduction}

With the increasing number of Internet users, creating a more economical, efficient, and effective virtual market for online businesses that provide both buyers and sellers a good advantage. That's what underlies consumers and producers to make transactions via an online shop, including IKEA Indonesia. IKEA is a retail company that sells furniture and home decor from Sweden. In 2014, IKEA first opened its branch in Indonesia that located in Alam Sutera area, Tangerang, Indonesia. To cover wider area in Indonesia, IKEA besides providing offline store in Tangerang also provides an online store that can be accessed on www.ikea.com/id, as seen on Figure 1 is the display page of IKEA Indonesia Website.

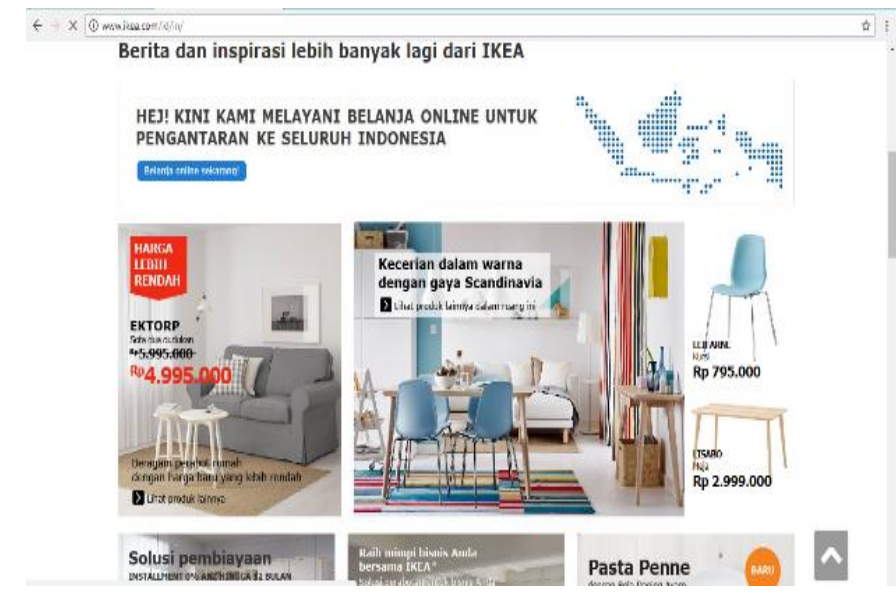

Figure 1

Display Page of IKEA Indonesia Website (Source: IKEA Website)

The tendency of consumers in shopping for furniture is very different from shopping for other goods or services, because furniture is expected to be stored and used in a long time. Considering that, consumers tend to want to shop directly to offline stores in order to see, feel and check quality directly because of many aspects that are assessed such as the quality of materials, models, colors and more. Another consideration is that consumers do not have to worry about being burdened with expensive postage because some furniture can be carried by themselves using private cars.

Compared with competitors who are equally engaged in the furniture and home decor business, IKEA continues to innovate and expand its wings in online sales compared to offline where competitors are more targeted offline market than online. As claimed by IKEA, the advantage of buying IKEA product that different from other furniture stores, IKEA ventured to sell online by utilizing some uniqueness that is only owned by IKEA, for example is all furniture and home decor sold by IKEA 
wrapped with "flat packs" which means the goods are not in a state already assembled but requires assembly if it arrives at the destination. With this flat packs, IKEA consumers do not have to worry if the goods shipped through the expedition will be exposed to volume due to its expedition-friendly packaging.

Even IKEA Indonesia develops IKEA online point innovation spread across various cities in Indonesia with the intention of making it easy for IKEA customers to shop online, so IKEA becomes closer and easier to access. There are five easy steps to shop for IKEA products online at IKEA Online Point: First, customers choose IKEA products through the official website to search, compare and select products using online kiosk. After that, the customer simply enters the desired product into the shopping cart and proceed to the payment page. Payment can be made via bank transfer or by credit card. Within 24 hours, IKEA will contact the customer for arrangement of delivery schedule. After the order confirmation is made, IKEA will deliver the order product to the given address. Delivery areas include Jakarta, Bogor, Depok, Tangerang, Bekasi, Bandung, Surabaya, and Semarang.

Based on this background, this study intends to analyze what factors are driving consumers in shopping for furniture online especially on the website of IKEA Indonesia.

\section{Literature Review}

According to Broekhuizhen (2009) there are six online purchasing variables: Service Quality, Merchandise Quality, Price Attractiveness, Perceived Risk, Time and Effort Saving and Enjoyment

- Service Quality

The elements that apply to online service quality according to Broekhuizen are personal interaction (friendliness, helpfulness, assurance, responsive of employee), service policies (return handling and warranties), tangible, reliability, and problem solving.

- Merchandise Quality

It is the quality of the merchandise as a perception of the overall quality of the merchandise perceptions and the variety of goods provided by online and offline retailers. The quality of the merchandise consists of quantity, quality and alternative composition.

- Price Attractiveness

Price is one of the keys to consumers when choosing a retailer. Monetary price is defined as the customer's perception of the price offered by online and offline retailers, made by comparing the observed price with the internal reference price.

- Perceived Risk

Risk perception is an uncertainty that consumers face when they cannot predict the future consequences of purchasing decisions. In online trading transactions there are four possible risks: product risk, transaction risk, psychological risk, and time risk. Product risk refers to the uncertainty that the product to be purchased will be as expected. While transaction risk is the uncertainty that will adversely affect consumers in the transaction process. Psychological risks are fears that may occur during purchase or after purchase. While the risk of time is the inappropriateness that will occur at the time of payment, packaging or delivery of goods.

- Time and effort savings

The cost of time and effort refers to the customer's perception of the time or effort required to shop through online or offline channels. Comfort and time show that consumers generally view time and effort as a cost.

- Enjoyment

Enjoyment is a pleasure to capture the intrinsic value that comes from shopping experience such as visual appeal, fun, passion and surprise. 
While according to Zeithaml and Maholtra (2005) there are eleven variables that drive a person to shop online includes Reliability, Responsiveness, Access, Flexibility, Ease of Navigation, Efficiency, Assurance Test, Security / Privacy, Price Knowledge, Site Aesthetics, and Customization.

- Reliability

Reliability is one of the important factors that has the most effect on online shopping. Reliability is closely related to risk because it is a measure of customer perception about whether or not traders can be relied upon to fulfill their promises

- Responsiveness

Is an action to help consumers and provide services with responsiveness. This responsiveness can mean the response or alertness in helping the customer and providing fast service.

- Access

It is to provide service in the same hour or time with the customer and the communication channel is easy to contact.

- Flexibility

Flexibility is able to adjust to customer demand and supply (criteria related to the process of a good).

- Ease of navigation

Ease of navigation that is in the site has a function that allows users to find services in terms of what is needed, have a good search engine, and facilitate service users to maneuver and back and forth from each page of the site.

- Efficiency

The ease of the site to be used, structured proportionately, and requires only a little information to be used by service users.

- Assurance / Trust

Assurance / trust is the knowledge, ability, and courtesy of the seller to cultivate the trust of consumers and consumers can entrust everything to the seller in the transaction.

- Security / Privacy

Zeithaml (2005) security and privacy is a buyer safe feeling from all risk hazards and hesitations in transacting with the seller. These aspects include financial security (security safety) and confidentiality (confidentiality).

- Price knowledge

It is how capable the service user can know the postage, the total price and the comparison price during the process.

- Site aesthetics

Associate with site view.

- Customization

It is how much and how easily the site can be modified according to the users' wishes, histories, and how to shop 


\begin{tabular}{|c|c|}
\hline Broekhuizen (2009) & $\begin{array}{l}\text { Zeithami and Maholtra } \\
\qquad(2005) \\
\end{array}$ \\
\hline $\begin{array}{l}\text { Service Quality } \\
\text { Merchandise } \\
\text { Quality } \\
\text { Price } \\
\text { Attractiveness } \\
\text { Time and Effort } \\
\text { Saving } \\
\text { Perceived Risk } \\
\text { Enjoyment }\end{array}$ & $\begin{array}{l}\text { Reliability } \\
\text { Responsiveness } \\
\text { Access } \\
\text { Flexibility } \\
\text { Ease of Navigation } \\
\text { Efficiency } \\
\text { Assurance/Trust } \\
\text { Security/Privacy } \\
\text { Price Knowledge } \\
\text { Site Aesthetics } \\
\text { Customization }\end{array}$ \\
\hline \multicolumn{2}{|c|}{$\begin{array}{c}\text { Factors That Driving Online Purchases On } \\
\text { IKEA Indonesia Website }\end{array}$} \\
\hline $\begin{array}{l}\text { Service Quality } \\
\text { Merchandise Quality } \\
\text { Price Attractiveness } \\
\text { Time and Effort Savi } \\
\text { Perceived Risk } \\
\text { Enjoyment } \\
\text { Access } \\
\text { Flexibility } \\
\text { Ease of Navigation } \\
\text { Efficiency } \\
\text { Security/Privacy } \\
\text { Price Knowledge } \\
\text { Site Aesthetics } \\
\text { Customization }\end{array}$ & ing \\
\hline
\end{tabular}

Figure 2

Ground Theory

From two ground theory that developed by Broekhuizhen (2009) and Zeithaml and Maholtra (2005) as seen on Figure 2, 14 variables chosen that includes Service Quality, Merchandise Quality, Price Attractiveness, Perceived Risk, Time \& Effort Savings, Enjoyment, Flexibility, Efficiency, Access, Ease of Navigation, Price Knowledge, Site Aesthetics, and Customization that will be the variable in this study. These variables will be investigated to determine which variables are the driving factors of purchasing furniture online by IKEA Indonesia consumers on the IKEA Indonesia website. Reliability, Assurance / Trust and Responsiveness Variables are incorporated into Service Quality variables which according to the theory proposed by Broekhuizen (2009) that the three variables can be combined.

\section{Method}

The technique used in this research is nonprobability sampling technique with incidental sampling type, that is sample determination method based on chance, any member of the population who met the researcher and willing to be the respondent can be sampled, if viewed by the person who happened to meet it is suitable as data source. (Sugiyono, 2012: 85). There is no minimum sample size received in the factor analysis. The larger the sample size, factor analysis becomes more accurate. Preferably the sample size should be 100 or more. Factor analysis can't be done if the sample size is less than 50. (Simamora, 2005: 108). Due to the limitations and difficulties of researchers in obtaining the number of consumers IKEA Indonesia that experience shopping online at IKEA Indonesia Website and is not known for sure, then to save time, effort, and cost then the data collection is done by using 
the formula Bernoulii (Riduwan \& Kuncoro, 2007: 40). From the Bernoulii's formula has been calculated then the minimum sample that can be used is 97 . In the analysis of factors required a sample of more than 100 respondents, funds in this study the author took as many as 120 respondents and known minimal loading factor of 120 samples is 0.50 .

This data analysis uses Principal Component Analysis (PCA), a factor analysis method that extracts factors by using total variance in the analysis (Simamora, 2005: 109). This method produces factors that have the least specific variance and error variance. If there are several factors produced, the first factor produced is the factor that has the largest common variance, as well as the smallest specificity and error variance.

\section{Result and Discussion}

Factor analysis is employed to identify influencing factors that affect online purchase behavior of IKEA product through website developed by the company so that new factor or component can be found. After several step of factor analysis done, factor rotation is the step to maximize the loading value of each item in order to facilitate the determination factor. There are several steps as mentioned earlier to employed factor analysis, there are KMO and Barlett's Test that shows an MSA score is greater than 0.5, it indicates that a set of variable factors can be further processed using factor analysis. This study produced Barlett's Test of Sphericity (shown with the number of Chi Square) of 7842.076 with significant 0,000 which means there is a correlation between variables.

The contribution of each item to its component needs to be maximized through the rotation technique. The rotation used to maximize the contribution of each item to the component is the Varimax rotation method. This method is a method that maximizes the number of loading variants on each component without changing the value of its communality. The results of the rotation can be seen in the table 1 as follow: 
Table 1

Rotated Component Matrix

\begin{tabular}{|c|c|c|c|c|c|c|c|c|}
\hline & \multicolumn{8}{|c|}{ Rotated Component Matrix } \\
\hline & \multicolumn{8}{|c|}{ Component } \\
\hline & 1 & 2 & 3 & 4 & 5 & 6 & 7 & 8 \\
\hline 1 & .796 & 0.305 & ) & 0 & 0 & .232 & .349 & .374 \\
\hline 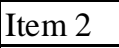 & 386 & 198 & & & & 432 & .198 & \\
\hline tem & 121 & 214 & & & & 611 & 0.301 & \\
\hline tem & 282 & 581 & $\rightarrow$ & & & 159 & .333 & \\
\hline tem 5 & 326 & 0.211 & 0.297 & 07 & 24 & 349 & 0.372 & 0.205 \\
\hline tem & 489 & 0.335 & 48 & & & 836 & 48 & 369 \\
\hline tem & 383 & 0.309 & 0.411 & 567 & 4 & 406 & 0.308 & 082 \\
\hline tem & 498 & 0.154 & 0.266 & 55 & & 101 & .478 & 201 \\
\hline en & 84 & 0.466 & 0.482 & & & 62 & 238 & .776 \\
\hline W & 323 & 0.046 & 07 & & & 708 & 388 & 036 \\
\hline ten & 6 & 0.246 & & & & 179 & & \\
\hline tem & 81 & 0.347 & 0.169 & 13 & & 247 & 0.466 & 55 \\
\hline tem 13 & 205 & 0.371 & 0.403 & 650 & & .006 & 0.227 & .48 \\
\hline Item 14 & 487 & 0.717 & 0.330 & 204 & & 330 & .466 & 36 \\
\hline Item & 39 & 0.613 & 0.277 & 33 & & 043 & .431 & .316 \\
\hline Item & & & & & & & & 460 \\
\hline & & & & & & 256 & & \\
\hline Item & 02 & 0.338 & 0.420 & 34 & & 476 & 0.476 & 105 \\
\hline Item 19 & 0.193 & 0.299 & 0.386 & 110 & 69 & 204 & 0.046 & 55 \\
\hline Item 20 & 0.135 & 0.045 & 0.252 & 813 & 364 & 356 & 0.406 & .352 \\
\hline Item 21 & 0.384 & 0.712 & 0.352 & .359 & 0.376 & 0.312 & 0.261 & 032 \\
\hline Iten & & & & & & 429 & 21 & \\
\hline Item 23 & & & & & & 0.268 & 570 & 37 \\
\hline Item 24 & 0.156 & 0.344 & 0.390 & & & 008 & 0.605 & 0.43 \\
\hline Item 25 & 0.374 & 0.056 & 0.465 & & & 0.034 & 0.796 & 0.20 \\
\hline Item 26 & 0.328 & 0.318 & 0.256 & 0.083 & 15 & 0.277 & 0.603 & 0.058 \\
\hline Item 27 & & & & & & 0.355 & 0.356 & 0.494 \\
\hline Item 28 & 0.101 & 0.233 & 0.356 & 0.476 & 0.270 & 0.259 & 0.100 & 0.621 \\
\hline Item 29 & 0.645 & 0.352 & 0.423 & 0.219 & 0.205 & 0.297 & 0.334 & 0.14 \\
\hline Item 30 & 0.332 & 0.431 & 0.085 & & & 0.012 & 0.753 & 0.24 \\
\hline Item 31 & 0.271 & 0.841 & 0.342 & 0.294 & & 0.397 & 0.267 & 0.471 \\
\hline Item 32 & 0.365 & 0.020 & 0.102 & 0.060 & 0.280 & 0.273 & 0.629 & 0.337 \\
\hline
\end{tabular}


Table 2

Component Labelling

\begin{tabular}{|c|c|c|c|c|c|c|c|}
\hline \multicolumn{2}{|c|}{ Component 1} & \multicolumn{2}{|c|}{ Component 2} & \multicolumn{2}{|c|}{ Component 3} & \multicolumn{2}{|c|}{ Component 4} \\
\hline Item & Loading & Item & Loading & Item & Loading & Item & Loading \\
\hline 1 & 0.796 & 4 & 0.581 & 16 & 0.685 & 7 & 0.567197749 \\
\hline 11 & 0.576 & 14 & 0.717 & 17 & 0.889 & 13 & 0.650088914 \\
\hline 18 & 0.602 & 15 & 0.613 & & & 20 & 0.813090095 \\
\hline \multirow[t]{3}{*}{29} & 0.645 & 21 & 0.712 & & & 27 & 0.538310324 \\
\hline & & 22 & 0.766 & & & & \\
\hline & & 31 & 0.841 & & & & \\
\hline Labelling: & Enjoyment & Labelling: & $\begin{array}{l}\text { Perceived } \\
\text { Risk }\end{array}$ & Labelling: & Efficiency & Labelling: & $\begin{array}{c}\text { Service and } \\
\text { Merchandise } \\
\text { Quality }\end{array}$ \\
\hline \multicolumn{2}{|c|}{ Component 5} & \multicolumn{2}{|c|}{ Component 6} & \multicolumn{2}{|c|}{ Component 7} & \multicolumn{2}{|c|}{ Component 8} \\
\hline Item & Loading & Item & Loading & Item & Loading & Item & Loading \\
\hline 5 & 0.724 & 3 & 0.611 & 23 & 0.570 & 2 & 0.805 \\
\hline \multirow[t]{5}{*}{8} & 0.609 & 6 & 0.836 & 24 & 0.605 & 9 & 0.776 \\
\hline & & 10 & 0.708 & 25 & 0.796 & 12 & 0.559 \\
\hline & & & & 26 & 0.603 & 19 & 0.556 \\
\hline & & & & 30 & 0.753 & 28 & 0.621 \\
\hline & & & & 32 & 0.629 & & \\
\hline Labelling: & $\begin{array}{c}\text { Ease of } \\
\text { Navigation }\end{array}$ & Labelling: & $\begin{array}{c}\text { Price } \\
\text { Attractiveness }\end{array}$ & Labelling: & Flexibility & Labelling: & Reliability \\
\hline
\end{tabular}

The results of the analysis shown on Table 2 that there are eight factors extracted or formed from factor analysis process. The eight factors are Enjoyment, Perceived Risk, Efficiency, Service \& Merchandise Quality, Ease of Navigation, Price Attractiveness, Flexibility and Reliability. Component labelling is done by judgment that refers to the theory. Due to its subjective nature, the results can be different if the interpretation is done by others.

- Enjoyment Factor

In the era of technology as it is today, humans increasingly cannot away from gadgets. Ease of information systems and supported by the speed of the internet, making someone addicted surfing in cyberspace including shopping online. Dependence on these gadgets can affect a person's lifestyle by getting excited when everything can be done with his gadget including when shopping online. It also shows that shopping online at IKEA's website provides enjoyment. Through some interviews to IKEA's consumers, it happened because IKEA furniture sold on the website with a full view of the interior so that consumers can imagine if they buy IKEA's furniture or home decor will generate the atmosphere of the room.

\section{- Perceived Risk Factor}

When shopping online, consumers experience uncertainty because consumers can't predict the future consequences of purchasing decisions that consumers take. Through an official website that is developed and managed by the company, a sense of trust will be higher than shopping online through online shop account in Instagram or other social media, because there is a reliable party that purchased goods will be delivered so as to reduce the risk of fraud. This also indicated that IKEA has convince their customer trust. 
- Efficiency Factor

Efficiency variables shows that IKEA's website availability of information and ease of transactions is in factors that can influence IKEA's consumer to shop online. If we take a look on IKEA's website, they even provide the assembly size so we can measure if its product fits with the room space. They also provide color availability, price, similar product and etc. IKEA's consumers also can pay trough debit or credit card with some options of several month installment. This factor is called efficiency because according to Ranganathan and Ganaphaty (2010), efficiency is the ease and speed of accessing and using a site that saves time in online shopping, items representing these factors indicate the ease of doing the transaction.

- Service \& Merchandise Quality Factor

This factor is called merchandise quality because the items representing this factor indicate the effect of product quality and product diversity. IKEA targets that everyone is a consumer, taking into account that IKEA has a strategy by providing a wide range of quality and price products that can be reached in each segment. IKEA also provides a variety of products, for example the sofa is provided in a variety of shapes, colors, materials and more tailored to the price and quality.

- Ease of Navigation Factor

This factor is called access because the items representing this factor indicate the effect of ease of ordering on the IKEA website. According to several interviews with IKEA consumers conducted in this study, IKEA website is classified as user friendly because consumers can easily access various information and make transactions even though it is the first time to shop online. IKEA's website is also supported with clear font sizes and types.

- Price Attractiveness Factor

In this factor, the seller needs to consider in providing a competitive product price, the items representing this factor indicate the influence of the attractiveness of the offered price. This is because on the website IKEA, if the consumer opens one of the products then at the bottom or right side of the website will appear a feature "similar product" that will make consumers have many options with more similar products with different price options in accordance with consumer's available budget. This makes it easier for consumers to be able to choose the product with the price closest to the budget owned by consumers

- Flexibility Factor

These factors indicate that consumer will purchase something online if there is a choice or options available to purchase, to pay and to delivery in accordance with the consumer's preferable.

- Reliability Factor

Reliability or reliability factors indicate that IKEA must demonstrate the ability of the company or online shop to provide the appropriate services promised accurately and reliably.

\section{Conclusion}

There are 8 driving factors of consumer to purchase furniture online on IKEA Indonesia's website: Enjoyment, Perceived Risk, Efficiency, Service \& Merchandise Quality, Ease of Navigation, Price Attractiveness, Flexibility and Reliability. By knowing what factors can affect consumers in doing online shopping for furniture, companies in this case IKEA Indonesia can optimize the use of its website in accordance with influential factors. 


\section{References}

Broekhuizen, T. (2006). Understanding Channel Purchase Intentions: Measuring Online and Offline Shopping Value Perceptions. Labyrinth Publications.

IKEA Indonesia Website. (2018). Retrieved from www.ikea.id

Ranganathan, C. \& Ganaphaty S. (2010). Information \& Management," in Key dimensions of business-to-consumer website.

Simamora, B. (2005). Analisis Multivariat Pemasaran. Jakarta: PT. Gramedia Pustaka Utama.

Sugiyono. (2009). Metode Penelitian Bisnis (Pendekatan Kuantitatif, Kualitatif, dan R\&D). Bandung: Alfabeta.

Ziethaml, V. A. \& Malhotra, A. (2005). E-S-QUAL A Multiple-Item Scale for Assessing Electronic Service Quality. Sage Publications, Volume 7. 